\title{
Monitoring Data Study of the Performance of Renewable Energy Systems in a Near Zero Energy Building in Spain: A Case Study
}

\author{
Javier M. Rey-Hernández ${ }^{1,2,3, *}$, Eloy Velasco-Gómez ${ }^{1,2}$ ( ) Julio F. San José-Alonso ${ }^{1,2}$, \\ Ana Tejero-González ${ }^{1,2}{ }^{\mathbb{D}}$, Sergio L. González-González ${ }^{1}$ and Francisco J. Rey-Martínez ${ }^{1,2}$ \\ 1 Department of Energy and Fluid mechanics, School of Engineering (EII), University of Valladolid (UVa), \\ 47011 Valladolid, Spain; eloy@eii.uva.es (E.V.-G.); julsan@eii.uva.es (J.F.S.J.-A.); anatej@eii.uva.es (A.T.-G.); \\ sergiolorenzo@eii.uva.es (S.L.G.-G.); rey@eii.uva.es (F.J.R.-M.) \\ 2 Institute of the Advanced Technologies of the Production (ITAP), University of Valladolid, 47002 Valladolid, Spain \\ 3 Higher Polytechnic College, European University Miguel de Cervantes (UEMC), 47012 Valladolid, Spain \\ * Correspondence: javier.rey@uva.es; Tel.: +34-983-423-366
}

Received: 12 September 2018; Accepted: 26 October 2018; Published: 1 November 2018

check for updates

\begin{abstract}
The building sector is responsible for a substantial part of the energy consumption and corresponding $\mathrm{CO}_{2}$ emissions. The European Union has consequently developed various directives, among which the updated Energy Performance of Buildings Directive 2018/844/EU stands out, aiming at minimizing the energy demand in buildings, improving the energy efficiency of their facilities and integrating renewable energies. The objective of the present study was to develop an analysis on the energy performance, related $\mathrm{CO}_{2}$ emissions and operating costs of the renewable energy technologies implemented within a multipurpose near Zero Energy Building (nZEB). The target building is an existing nZEB called LUCIA, located in Valladolid (Spain). Monitoring data provides the required information on the actual needs for electricity, cooling and heating. It is equipped with solar energy photovoltaic systems, a biomass boiler and a geothermal Earth to Air Heat Exchanger (EAHX) intended for meeting the ventilation thermal loads. All systems studied show favourable performances, but depend significantly on the particular characteristics of the building, the control algorithm and the climate of the location. Hence, design of these strategies for new nZEBs must consider all these factors. The combined use of the PhotoVoltaic PV System, the biomass and the EAHX reduces the $\mathrm{CO}_{2}$ emissions up to 123 to 170 tons/year in comparison with other fuels, entailing economic savings from the system operation of up to 43,000-50,000 €/ year.
\end{abstract}

Keywords: $\mathrm{CO}_{2}$ impact; energy analysis; near Zero Energy Buildings; energy consumption; economical costs; renewable energy

\section{Introduction}

In the European Union (EU), the increase of renewable energy technologies is a priority in order to meet the EU target of at least a $27 \%$ share for renewable energies by 2030 [1]. This could be increased to $66 \%$ in 2030 and 100\% in 2050, according to the European Renewable Energy Council 2012 (EREC) [2]. In addition to this, the building stock has grabbed the limelight of the EU energy targets because it accounts for about $40 \%$ of the European Union energy consumption. Considering these two facts and taking into account the recently amended Energy Performance of Buildings Directive (EPBD) of 30 May 2018 [3], the design of near Zero Energy Buildings (nZEB) that integrate renewable energies becomes imperative.

The requirements of a nZEB can be achieved firstly, by minimizing the energy demand through a careful passive design and then, by supplying the remaining thermal and electrical loads through 
active strategies [4,5]. The latter target can only be met through highly efficient Heat Ventilation Air Conditioning (HVAC), Domestic Hot Water (DHW), lighting, etc. equipment and, in this line, renewable energies must be taken into account [5]. Therefore, among the possible indicators that permit the identification of a nZEB is the Renewable Energy Ratio (RER), that calculates the share of renewable energy of the building [6].

There exist a number of different renewable energy technologies that can be implemented in buildings with the aim of achieving the nZEB requirements, as reviewed by Oh et al. [4]. Both photovoltaics (PV) and thermal solar energy systems are the most widespread alternatives with a number of alternative applications [7,8]. Good et al. [9] compared the potential of PV and solar thermal systems to achieve defined nZEB requirements, and indicated that high efficiency PV was the optimal solution for a simulated Norwegian residential building, with the particular systems installed. Also focusing on nZEB residential buildings, Tsalikis and Martinopoulos [7] insist on the dependence of the PV and solar thermal potential on the location and climatic conditions, yet they derive that PV would be viable and sufficient to meet the electricity demand.

Geothermal energy can be exploited not only with ground source heat pumps, but also implementing Earth to Air Heat Exchangers (EAHX) [10]. Ascione et al. [11] use EnergyPlus to simulate the energy savings and $\mathrm{CO}_{2}$ emissions achievable by an EAHX if installed at a multipurpose nZEB in Palermo, which yielded higher reductions for the summer period. They propose installation together with PV to actually meet nZEB requirements. Thiers and Peuportier [12] proposed a ventilation system combining heat recovery and an EAHX for a "Passivhaus" dwelling in France, obtaining a considerable reduction in summer discomfort, primary energy consumption and global warming potential. Also for passive residential houses, night ventilation has demonstrated great potential when operating between 23:00 and 7:00 during the harshest summer months [13] and should be considered to further improve thermal comfort in a nZEB. An experimental study developed by Vaz et al. [14] showed better thermal conditions inside a building in the south of Brazil, evaluating the transient behaviour of both the soil and the air. Woodson et al. [15] also performed experimental measures on an EAHX in Burkina Faso, where soil temperatures were maintained at about $30.4^{\circ} \mathrm{C}$ at $1.5 \mathrm{~m}$ depth even during extreme outdoor temperatures, achieving temperature drops in the air above $7.5^{\circ} \mathrm{C}$. Further experimental and simulation research have demonstrated the interest of EAHX to minimize the energy consumption and related emissions of conventional air conditioning, due to the almost constant ground temperature at about 1.5 to $2 \mathrm{~m}$ depth, which is called "earth's undisturbed temperature" [16]. However, for an efficient EAHX it is important to understand the ground thermal saturation and recovery; thus, an intermittent mode of operation could be recommendable [17].

Although the integration of biomass is among the possible power solutions aimed at achieving a nZEB [5], there is limited research in the literature that focuses on this alternative. To the knowledge of the authors, there is no specific monitoring work published on biomass solutions implemented in nZEBs. Ayman et al. [18] simulated and compared, with the TRNSYS software (Thermal Energy System Specialists, LLC, Madison, WI, USA), five conventional and seven (either biomass or shared) combined heat and power energy systems for a standard or passive residential house in Finland. Their evaluation of primary energy and equivalent $\mathrm{CO}_{2}$ emissions for Finnish and international factors, as well as site energy and energy cost, showed that centralized power supply is still more interesting for residential houses than an individualized biomass combined heat and power system. Moran et al. [19] also questioned the interest in exporting electrical energy with a Combined Heat and Power (CHP) system installed in residential houses in temperate climates, in terms of cost optimal levels and sustainability. By comparing eight case studies of a semi-detached house in Ireland with different implemented strategies, they concluded that it is preferable to minimise the indoor thermal loads by means of greater insulation and then supply the remaining energy demand through a biomass boiler or a heat pump, rather than implementing a CHP.

Finally, despite the non-negligible number of existing research works on wind power generation for nZEBs [4], it is not as widespread for building energy supply as other solutions. One possible 
reason is that an effective design in urban areas implies a detailed study of the local topography and particular conditions, the wind direction, speed and turbulence [20]. For instance, on-shore wind energy, despite being one of the most cost-effective solutions for renewable electricity production in Denmark, it is not expected to be installed near new buildings [21].

From these results available in the literature, it can be observed that the degree up to which a particular renewable energy can efficiently achieve the nZEB purposes, is highly dependent on the location and the combined behaviour of the various strategies implemented. Moreover, little research presents the actual behaviour of representative nZEBs in Europe. Monitoring of the performance of real nZEBs permits the designers to compile feedback for the better selection of strategies for nZEBs in similar climates, serves as reference for decision making on the necessary adjustments to be implemented as well as to provide real data to validate dynamic building energy models [22]. This paper provides and analyses experimental data obtained through dynamic monitoring of a solar PV, biomass boiler and an EAHX geothermal system implemented in a multipurpose nZEB situated in the city of Valladolid, Spain. The final aim is to give evidence of the actual interest of implementing these strategies within a building nZEB at the particular location and provide experimental data for validation of the different features of a nZEB.

\section{Case Study}

The target building for this case study is a real building called LUCIA, designed to be nZEB and near zero $\mathrm{CO}_{2}$ emissions using renewable energies (Table 1). The building, which belongs to the University of Valladolid, was indeed intended as an "on-field" laboratory for the application of innovative and renewable energy technologies. The energy model of a nZEB shown in Figure 1 was followed at a design stage and quality checks were also carried out during the construction to ensure that the provided model and the actual building characteristics match, as recommended [23,24].

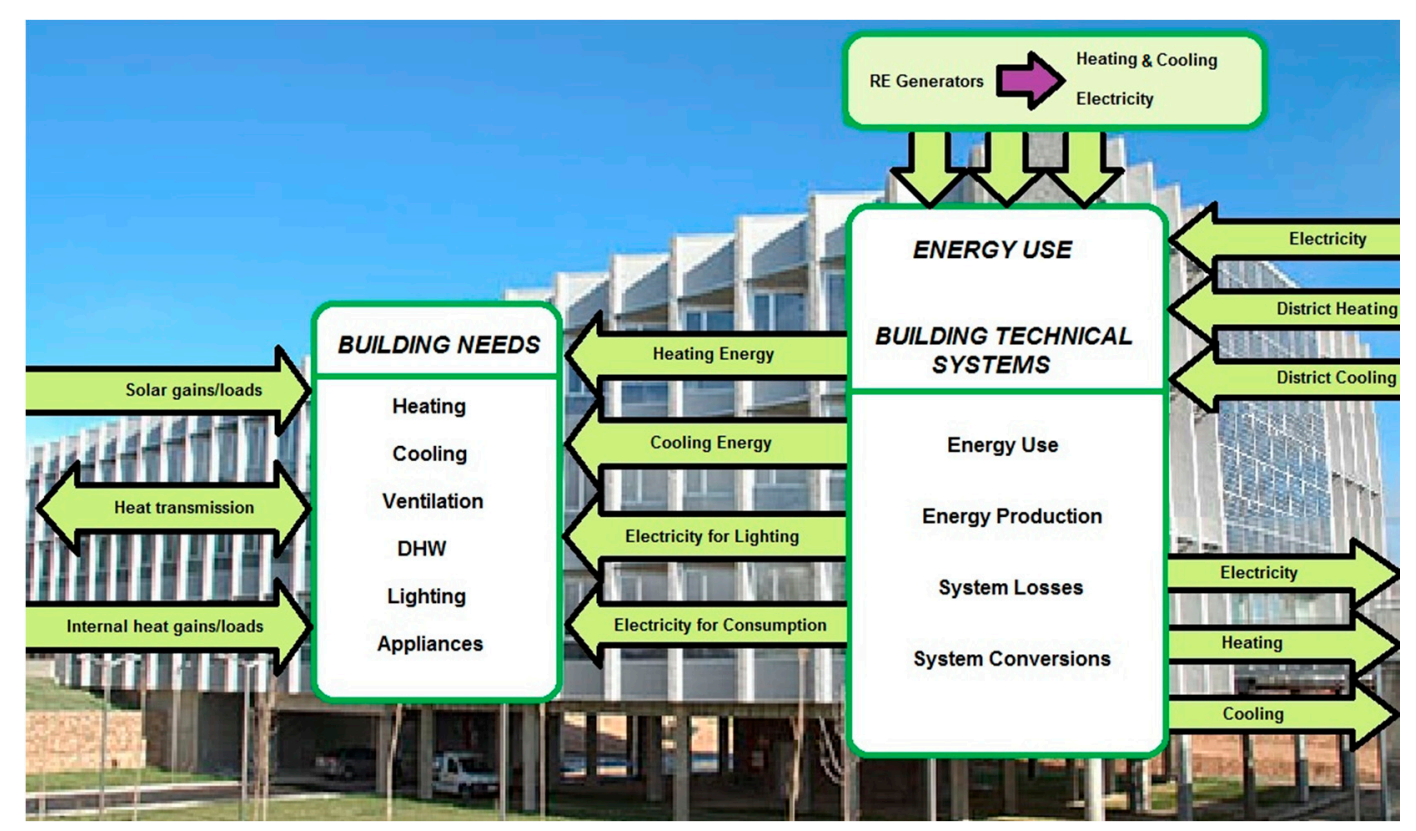

Figure 1. Features of energy design of a near Zero Energy Buildings (nZEB).

According to the latest Köppen-Geiger classification, the typical climate of the location is $\mathrm{Csb}$, hence a temperate climate with dry, warm summers [25]. Regarding some of the climate parameters [6], radiation available is relevant during most of the year. Despite being considered as a "temperate" climate at a World scale, outdoor temperatures during winter are low enough to make heat recovery quite interesting. During summer days, large variations of temperature occur, which favors free-cooling [26]. 
Table 1. Characteristics of LUCIA near Zero Energy Building (nZEB).

\begin{tabular}{ccc}
\hline LUCIA nZEB Features & Facilities & Set Points \\
\hline Area $7500 \mathrm{~m}^{2}$ & Biomass Boiler $300 \mathrm{~kW}$ & Summer $26^{\circ} \mathrm{C}$ \\
Laboratories Area $5150 \mathrm{~m}^{2}$ & Absorption System $176 \mathrm{~kW}$ (EER 0.7) & Winter $21^{\circ} \mathrm{C}$ \\
Volume $22,500 \mathrm{~m}^{3}$ & Conventional Air Cooling system $232.7 \mathrm{~kW}$ (EER 3.3) & Humidity $40-60 \%$ \\
Thermal transmittance $0.157 \mathrm{~W} / \mathrm{m}^{2} \mathrm{~K}$ & EAHX 56 wells, 0.2 m diameter, $16 \mathrm{~m}$ bured pipes & \\
DALI (T5 and LED) $9.7 \mathrm{~W} / \mathrm{m}^{2}$ & HVAC by 4-tube fancoil system & \\
Solar Tubes (Natural Lighting) & SCADA (DESIGO, Siemens) & \\
ZigZag Shaped Façade (auto shading) & & \\
South orientation & & \\
\hline
\end{tabular}

The building under study is considered one of the leading nZEBs in the world, qualified with the second highest Leadership in Energy and Environmental Design LEED score in the world [27], among other certifications [6,28]. Its bioclimatic design, increased insulation, passive ventilation and other strategies allow a reduction in building thermal energy requirements by more than $50 \%$. The main constructive peculiarity is the zigzag shaped façade to reorient the windows to the south, all equipped with carefully designed shadowing. Indoor thermal loads are minimized through double-glazing argon-filled windows and an optimally thermal insulated envelope. The large glazed façade, covering $46 \%$ of the total vertical wall area, together with light tubes and high efficiency luminaries, whose intensity is controlled by occupancy and lux level, enable $45 \%$ savings in lighting. One further design consideration was the Life Cycle Analysis of materials. Construction elements and materials are partly recycled and they are all certified for their low emissions and energy consumption during their manufacture. Finally, this building provides new water saving systems through the reuse of rainwater, from the parking and the roof, and gray water with separation networks in the laboratories, which allow treatment prior to discharge; taps with integrated electronic technology, with the capacity to supply a reduced and optimal flow. A green roof with local vegetation, which does not need additional irrigation, helps to counteract the urban-heat-island effect [6,28].The renewable energy technologies designed, implemented and monitored in the LUCIA building are described next.

\subsection{Renewable Energies Implemented in the LUCIA nZEB}

The design RER of the LUCIA building is 0.66 [6]. It was planned to reduce the use of non-renewable resources by $31 \%$, compared to the primary energy of a standard building, and the building's impact on climate change by more than $90 \%$.

The building provides simple solutions for the architectural integration of solar energy PV. The modules are integrated within the glazing to permit PV generation without hindering natural lighting. One set of PV modules are installed on the southeast façade, integrated as a ventilated facade system (Figure 2a), and three further systems in the skylights (Figure 2b).

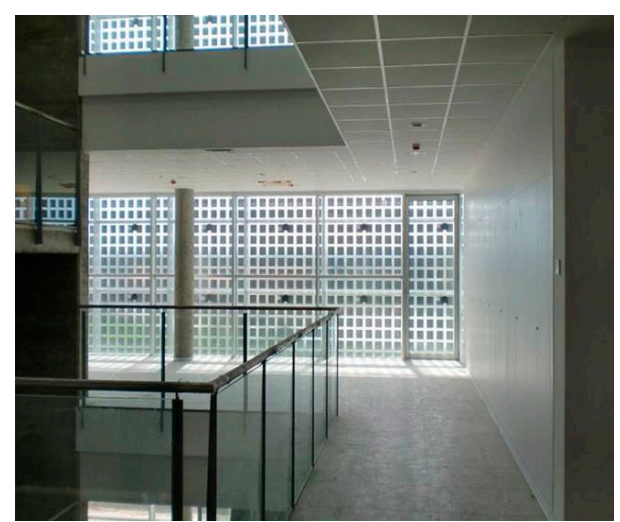

(a)

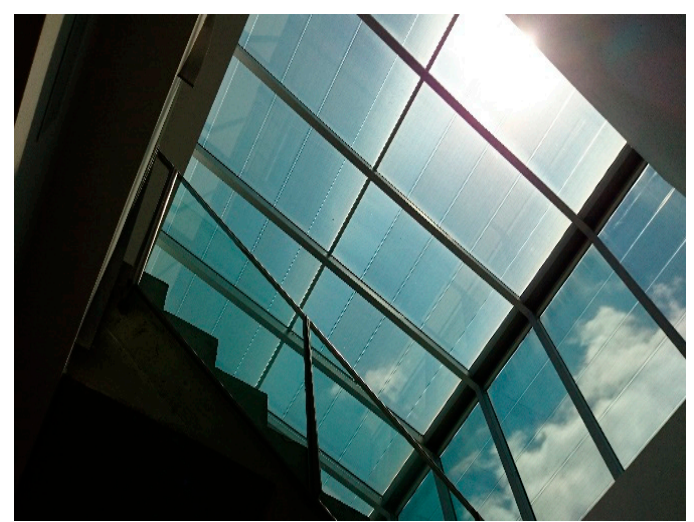

(b)

Figure 2. (a) View from inside of PhotoVoltaics PV modules in façade; (b) View from inside of one of the PV modules in the roof. 
Façade PV modules (hereinafter referred as "PV 1") consist of 6"polycrystalline cells, with dimensions $1730 \times 1015 \times 35 \mathrm{~mm}$. The other three PV modules (PV 2, PV 3 and PV 4) on the roof are amorphous silicon. Each pane of the skylights has dimensions of $2120 \times 1245 \mathrm{~mm}$. Table 2 gathers the characteristics of the photovoltaic panels installed in each zone. The analysis registers the data of the largest system separately from the remaining three.

Table 2. Photo Voltaic Systems installed.

\begin{tabular}{ccccc}
\hline & \multicolumn{2}{c}{ PV $_{\text {Facade }}$} & \multicolumn{2}{c}{ PV $_{\text {Roof }}$} \\
\cline { 2 - 5 } & PV 1 & PV 2 & PV 3 & PV 4 \\
\hline Power $(\mathrm{W})$ & 10,080 & 1680 & 840 & 2520 \\
Power per item $(\mathrm{W})$ & 180 & 140 & 140 & 140 \\
Total surface covered $\left(\mathrm{m}^{2}\right)$ & 98.33 & 42.58 & 21.29 & 63.87 \\
Inversor Power $(\mathrm{W})$ & 10,000 & 2000 & 1200 & 2500 \\
Azimuth & $35^{\circ}$ & $35^{\circ}$ & $35^{\circ}$ & $145^{\circ}$ \\
Tilt Angle & $90^{\circ}$ & $5^{\circ}$ & $90^{\circ}$ & $5^{\circ}$ \\
\hline
\end{tabular}

High efficient HVAC systems meet the remaining thermal demand that cannot be met by the passive strategies described before. An air-water HVAC system was chosen instead of an all air system, to supply heating and cooling independently from the required ventilation rate. Heating and cooling to the different indoor spaces are supplied by 4 -tube fancoil systems that permit simultaneous cooling and heating and control of individual demand.

The biomass boiler was designed to provide the heating and partial cooling demand of the building by single effect absorption system. The biomass boiler (Figure 3), whose nominal power is $329 \mathrm{~kW}$ and its performance factor 0.88 , supplies heating. It is fueled with wood chips, widely available in the region where the building is located, being G30 H20 forest biomass chips in accordance with the Austrian standards (Önorm M7 133) [29], with a Low Heating Value (LHV) of 3.6 kWh/kg.

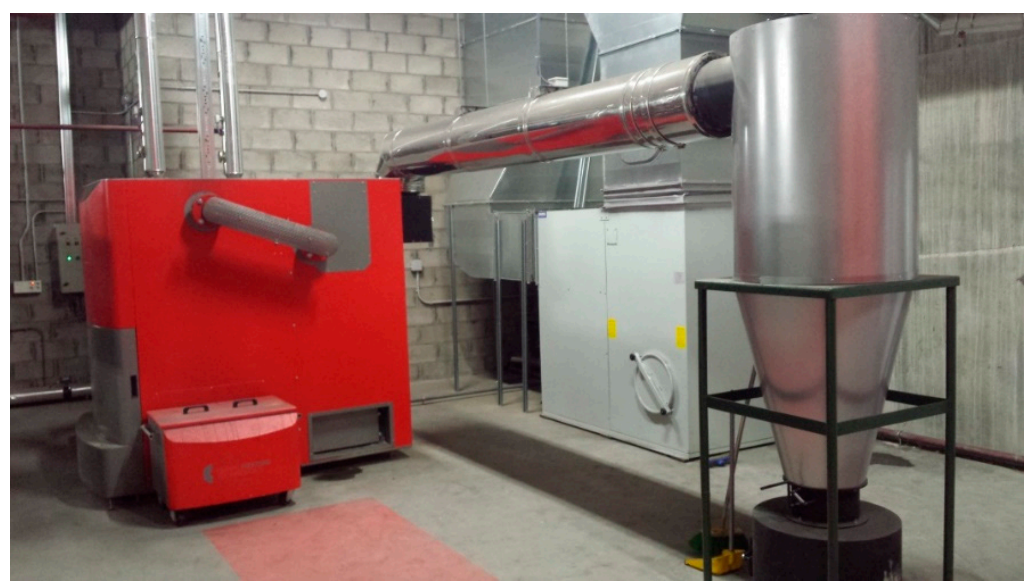

Figure 3. Heat Energy System. Biomass boiler, (SmartHeatingTechnology, Smart300, 300 kW).

An absorption cycle of $176 \mathrm{~kW}$ and Energy Efficiency Ratio (EER) 0.7 and an auxiliary conventional chiller of $232.7 \mathrm{~kW}$ and EER 3.3 provide the refrigeration demand. A cooling tower enables the removal of the residual heat produced by the absorption system.

The building's Air Handling Unit (AHU) provides 100\% outdoor air ventilation, which reaches $15,000 \mathrm{~m}^{3} / \mathrm{h}$. The AHU is equipped with a plate-type heat recovery economizer and permits operation in free-cooling mode. When free-cooling is not enough to reach indoor comfort, an EAHX system is used. When neither the former nor the latter are enough to achieve thermal comfort/supply the ventilation loads, the heat recovery starts operating. The biomass heating and the absorption cooling supply the remaining loads that the combined ventilation system cannot meet. 
The Earth Air Heat Exchanger (EAHX), also known as Canadian wells, has 52 wells of $16 \mathrm{~m}$ length with a diameter of $200 \mathrm{~mm}$ (Figure 4). The EAHX is integrated in the LUCIA nZEB under clay soil with a calorific value of $0.8 \mathrm{~kJ} /\left(\mathrm{kg} \cdot{ }^{\circ} \mathrm{C}\right)$, density $2700 \mathrm{~kg} / \mathrm{m}^{3}$ and thermal conductivity $2.9 \mathrm{~W} /\left(\mathrm{m} \cdot{ }^{\circ} \mathrm{C}\right)$. The ground volume is large enough to expect achieving important reductions in the energy demand during the operating periods, without risk of thermal saturation of the ground.
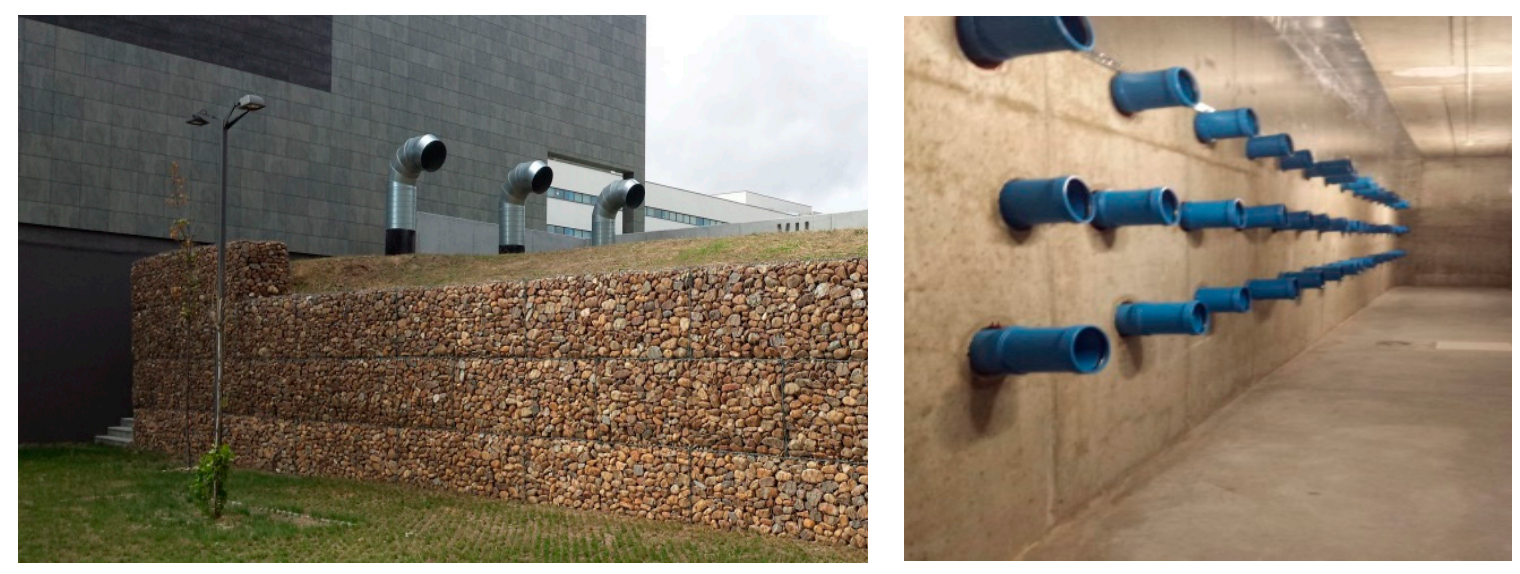

Figure 4. Geothermal system (EAHX). View from outside (left) and inside (right).

The enthalpy-based control system of the AHU aims for the optimal set points, taking into account the consumption of the auxiliary elements involved in the operation of the different technologies. It establishes four modes of operation: With EAHX, no EAHX and with the option of working with or without free-cooling, and with the possibility of adding the heat recovery option. To sum up, the management modalities could be: with EAHX and heat recovery, no EAHX and heat recovery, or just free-cooling, where neither the EAHX nor the heat recovery systems are working.

The control system implemented in the energy systems dedicated to the pre-treatment of ventilation air, aims to reach the set points through the cheapest energy system due to an enthalpy control, taking into account the consumption of the auxiliary elements involved in the use of the different technologies.

First of all a free-cooling System would be implemented. When free-cooling is not enough to reach the comfort values, the EAHX system is used. When the use of the two previous ones is not enough to approach the desired comfort, the Heat Recovery Exchanger will be used. Finally, when none of the above are sufficient to reach the set points, the absorption and cooling system must be used.

However, not all technologies can always be used. The conditions for the use of the different technologies depend on the values of the environmental conditions. For instance, during most daytimes in summer, free cooling cannot be used because the outside air has a higher temperature than the room temperature. However in winter, the external conditions will usually be more unfavourable than those of the air from the Heat Recovery Exchanger or the EAHX. Therefore, free cooling will not be used when the external conditions are more unfavourable than the conditions of the ventilation air provided by the other available technologies.

Despite their high efficiency, not every technology is always interesting. Therefore, the conditions for the combined operation of the different strategies depend on the climate conditions. This fact incurs in one of the reasons for the gap between the predicted behaviour of a nZEB at the design stage and the real performance once built [30]. Monitoring of the actual behaviour of the LUCIA building facilitates decision making towards more energy efficient operating modes, evaluate the gap between predicted and measured data, as well as to evaluate the convenience of the strategies selected for nZEBs located in a particular climate. 


\subsection{Monitoring Data}

The LUCIA building is controlled by an advanced control and management system called DESIGO $^{\mathrm{TM}}$, created by SIEMENS and based on Supervisory Control and Data Acquisition (SCADA) technology software [31]. Figure 5 shows a view of the interface. This system ensures optimal management of the HVAC, electricity, fires, alarms, registrations, comfort, Indoor Air Quality (IAQ), etc., guaranteeing that the energy supplied is always as minimal and efficient as possible. It allows a predictive control of the building, of use for maintenance and forecasting of the facilities energy demand. All variables measured are registered and analysed by the building's control system for subsequent consumption and maintenance reports.

The whole building and in particular the renewable energy facilities are being fully monitored with the aid of energy meters through the ModBus protocol [32]. Pulse counters enable the monitoring of the energy consumption from HVAC systems. There are almost 100 main analyzers throughout the building to measure the active energy, reactive energy, frequency of the zone and phase voltage through the ModBus protocol. They allow the possibility of a better control of the energy consumption and comfort level of each zone.

All energy parameters, such as energy consumption or operating temperatures, are accounted for and recorded with a pre-established period of time by the central building control and surveillance system.

Through this system, the data obtained due to its previous records is stored and with them, reports are generated regularly, with the aim of visualizing a continuous analysis of the consumption produced in the building. Figures 6-8 are examples of how the dynamic monitoring is going on in the three renewable energy systems studied for different days during the year 2017. Figures 6-8 show how the dynamic monitoring of the different energy systems is being carried out, and some random days are presented. In these figures, several dots are plotted as real-time dynamic monitoring (secondary $y$-axes), and the baseline of all aggregated data from the represented dynamic monitoring (primary $y$-axes). 


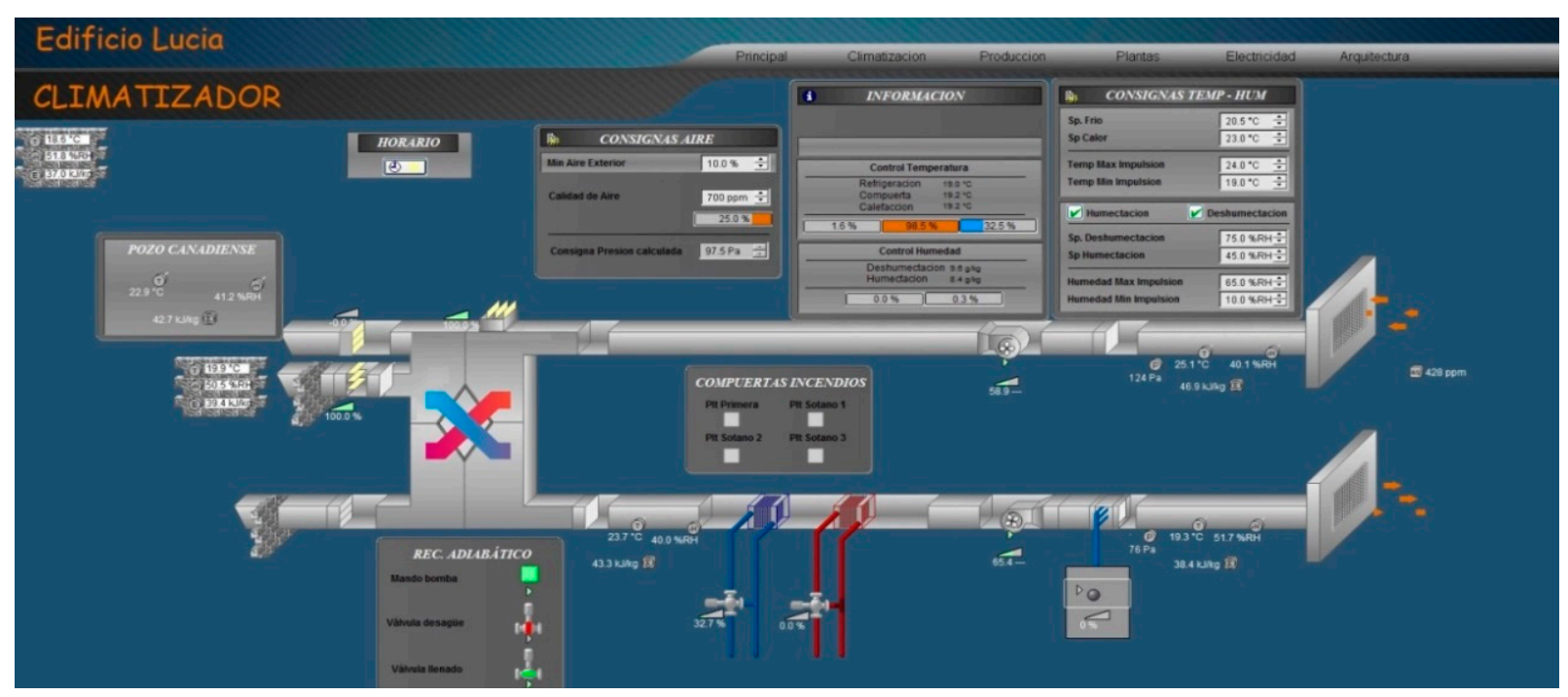

Figure 5. Screenshot of DESIGO, (SCADA Siemens). 


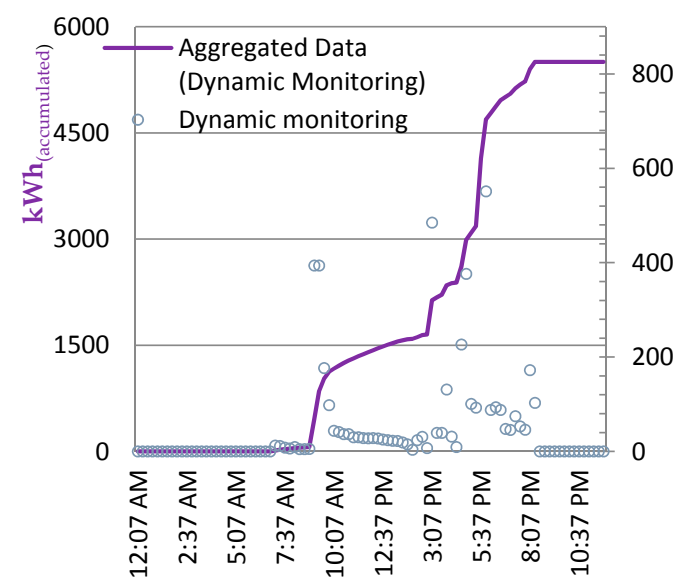

(a)

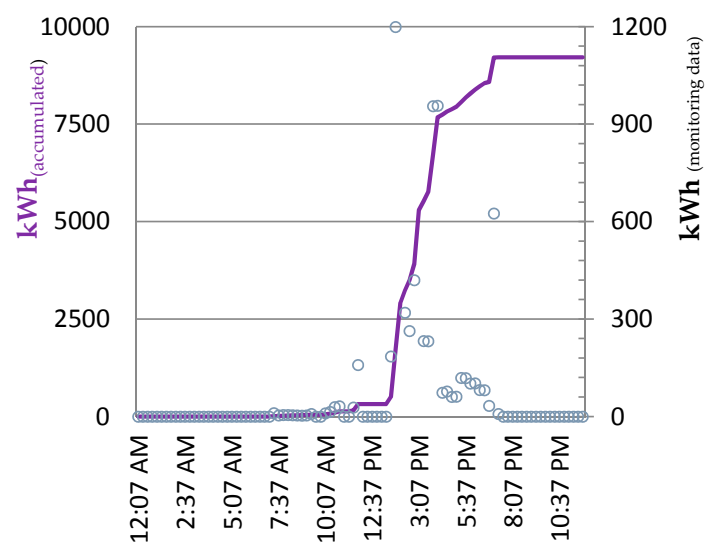

(c)

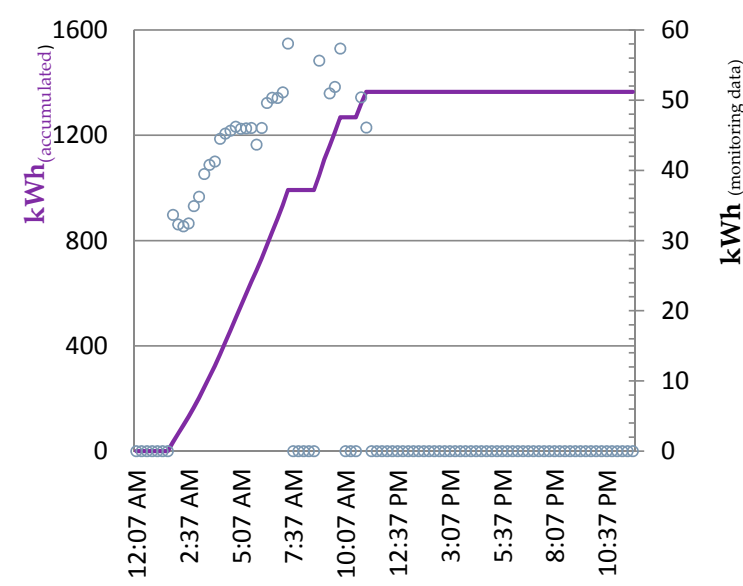

(b)

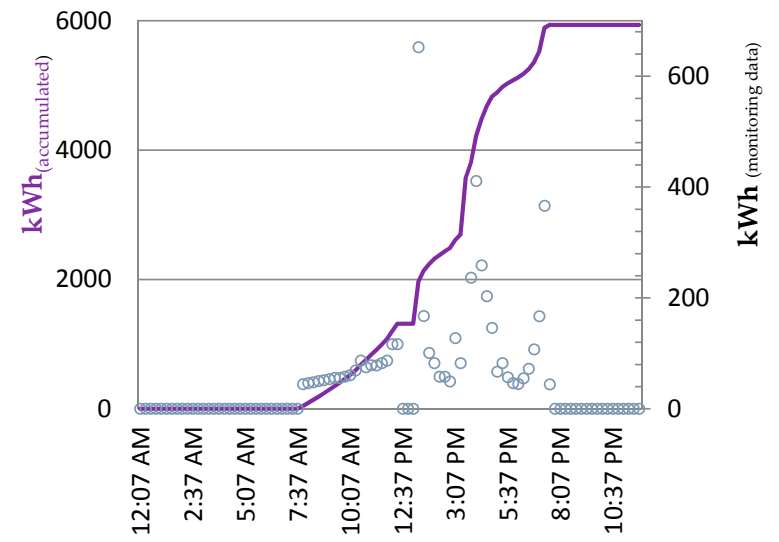

(d)

Figure 6. Monitoring data of EAHX: (a) June 14th. (b) January 9th. (c) May 10th. (d) October 27th.

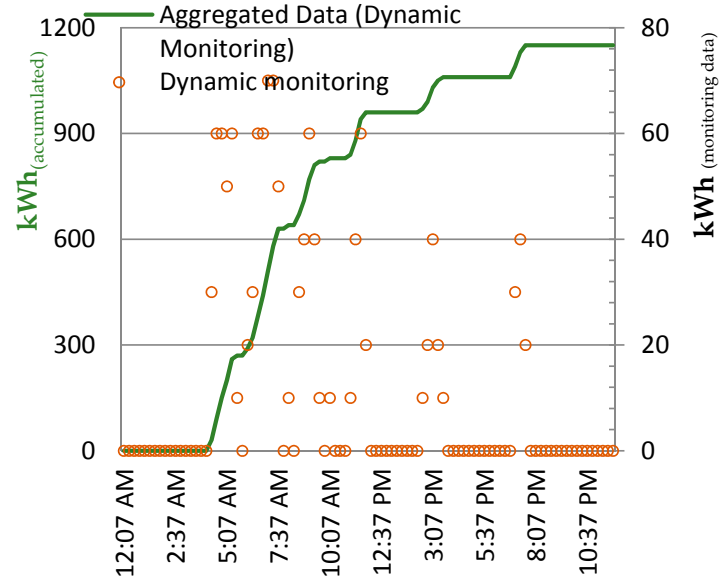

(a)

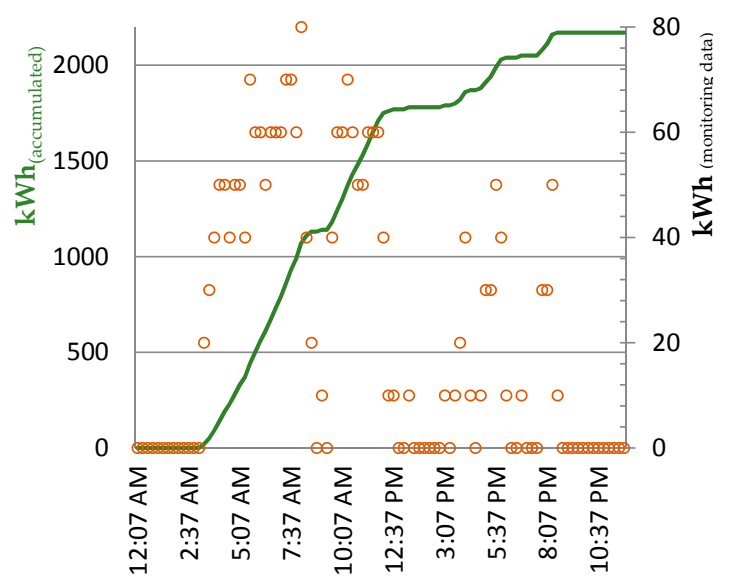

(b)

Figure 7. Monitoring data of biomass boiler: (a) February 22nd. (b) January 23rd. 


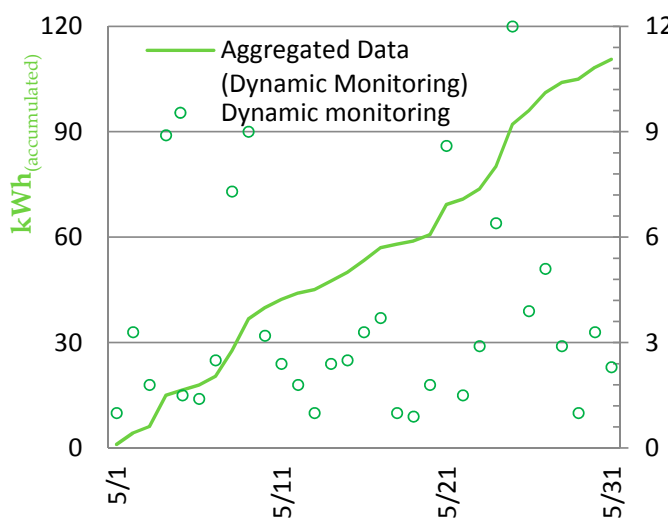

(a)

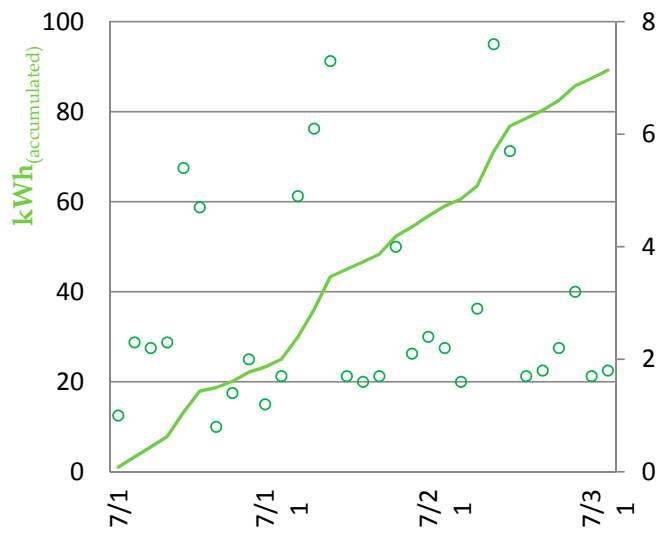

(c)

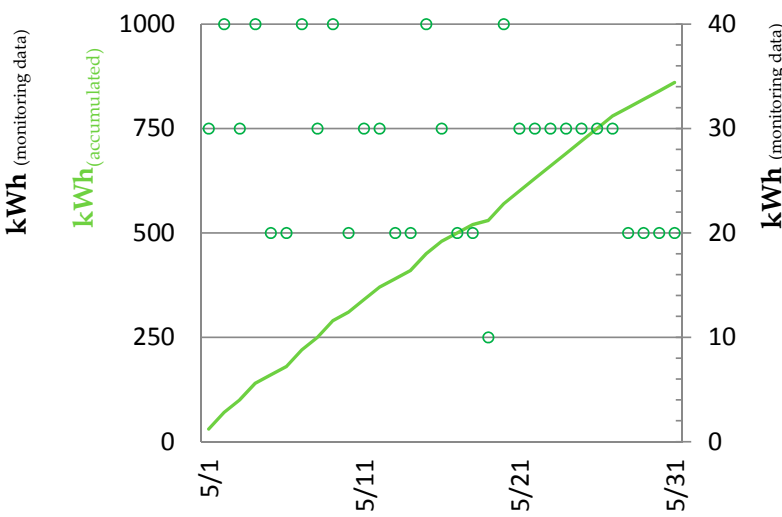

(b)

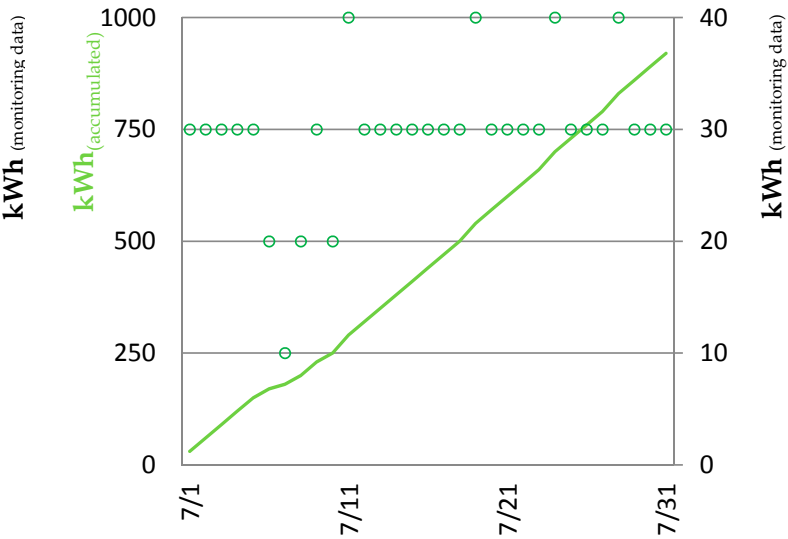

(d)

Figure 8. Monitoring data of: (a) PVSystem roof $_{\text {in May. (b) PVSystem facade }}$ in May. (c) PVSystem Proof $_{\text {in }}$ July. (d) PVSystem facade in July.

\section{Results and Discussion}

\subsection{Energy Consumption}

To identify the main energy requirements of the LUCIA, this study begins with an analysis of the energy consumption of the building. Table 3 shows the breakdown of the different energy consumption items of the building in MWh per year. HVAC consumption is segregated in supply and return air flows, due to the overpressure operating mode aimed at reducing infiltrations, thus improving IAQ.

Table 3. Energy Consumption in MWh of the LUCIA nZEB in 2017.

\begin{tabular}{ccc}
\hline Energy & Source of Energy Demand & MWh \\
\hline \multirow{2}{*}{ Cooling } & Chiller & 87.98 \\
& Absorption System & 34.22 \\
\hline \multirow{2}{*}{ Pumps \& Fans } & Supply air flow HVAC System & 62.30 \\
& Return air flow HVAC System & 55.11 \\
\hline \multirow{2}{*}{ Heating } & Indoor heating (biomass boiler) & 173.24 \\
& DHW (biomass boiler) & 7.22 \\
\hline Lighting & Lighting & 78.14 \\
\hline
\end{tabular}

It can be observed that almost half of the energy consumption is due to the cooling demand, while about $36 \%$ and $16 \%$ correspond to heating and lighting, respectively. Compared to the expected consumptions calculated during the design state. Lighting incurs into 78.14 MWh compared to the 
74.79 MWh expected at the design-stage, but still falls far below the common energy consumption for lighting in office buildings.

Figure 9 shows the evolution of the energy consumption breakdown along the year 2017, which fits to the expected behavior. The lighting demand slightly diminishes as daytime becomes longer, while the cooling demand increases sharply on summer months and heating on winter months.

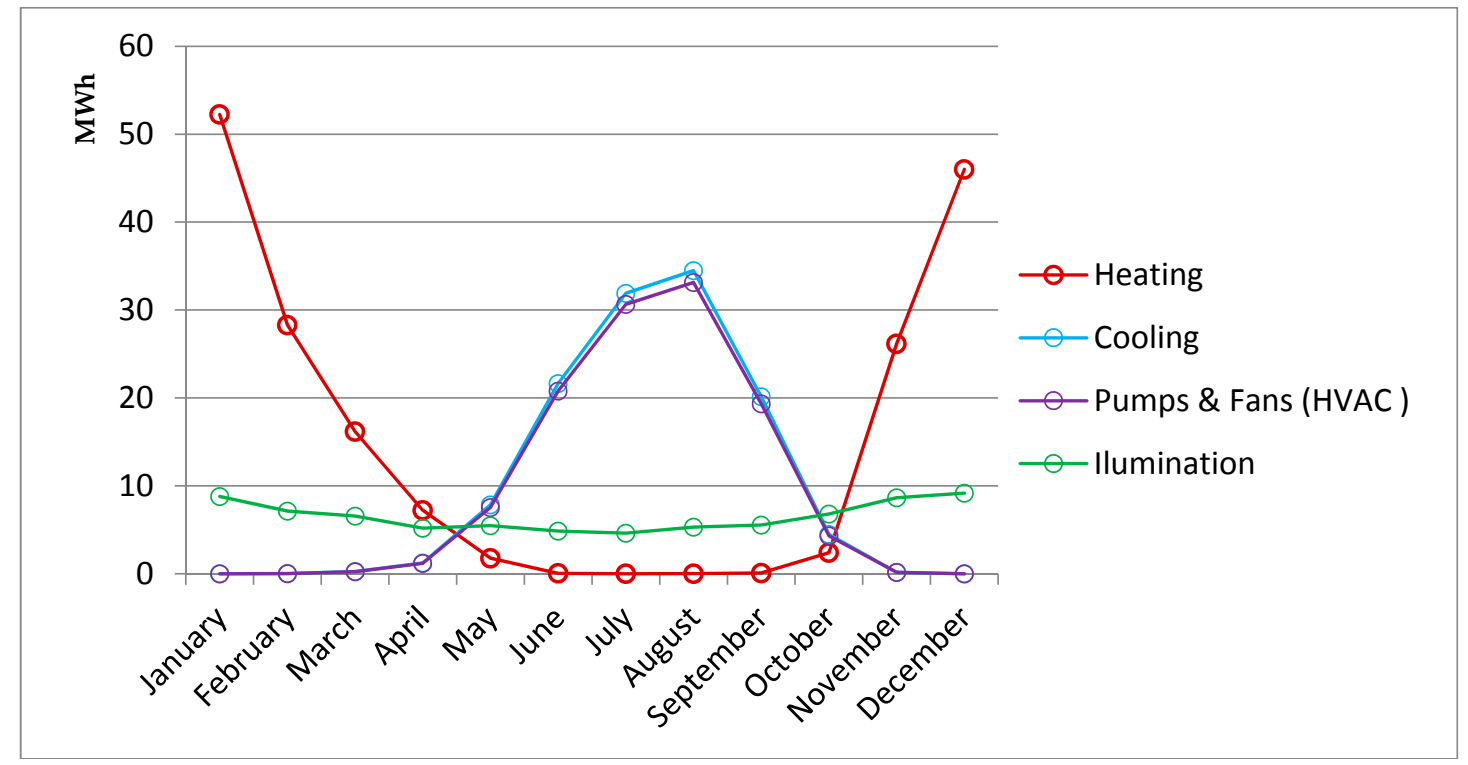

Figure 9. Evolution of energy consumption breakdown of LUCIA nZEB in 2017.

Up to $37 \%$ of the total energy consumption is due to the chiller, while absorption only represents $14 \%$ of total cooling consumption. The remaining $49 \%$ is almost equally divided between the supply and the return air flow from the HVAC system, which involve energy consumption of fans and pumps. The small difference between supply and return is justified by the overpressure mode of ventilation.

The heat generated is mainly used for indoor heating with comfort purposes $(81 \%)$, whereas DHW requirements only account for $4 \%$ of the total heat consumption. This is because the typical office and laboratory activities developed in this building incur into a low DHW demand. The remaining $15 \%$ is directed to the absorption cooling system, which concentrate during mid-seasons periods. These results of the monitoring strengthen the design decision of installing PV solar modules instead of solar thermal collectors.

\subsection{Biomass}

The first system to be studied in this paper is the biomass boiler. Figure 10 shows the energy supplied by this system along the year 2017. As expected, winter months are the most energy demanding. From May to mid-October, where the building demands barely any heat to maintain indoor comfort, heating consumption is limited to feed the absorption system for cooling, never exceeding $25 \mathrm{MWh}$. During the month of August, it can be seen how the building activity is limited to a minimum use. There is near no heating demand during September due to the absence of indoor heating requirements and the low cooling demand, which can be met mostly by the AHU alone through the combination of the heat recovery, free cooling and EAHX without requiring the operation of the absorption machine.

The amount of biomass supplied to the boiler is intrinsically related to the heating demand, as will be analysed later in Section 3.5. During the months where the cold is most extreme in the particular location, January and February, the fuel supply reaches 23 tons. 


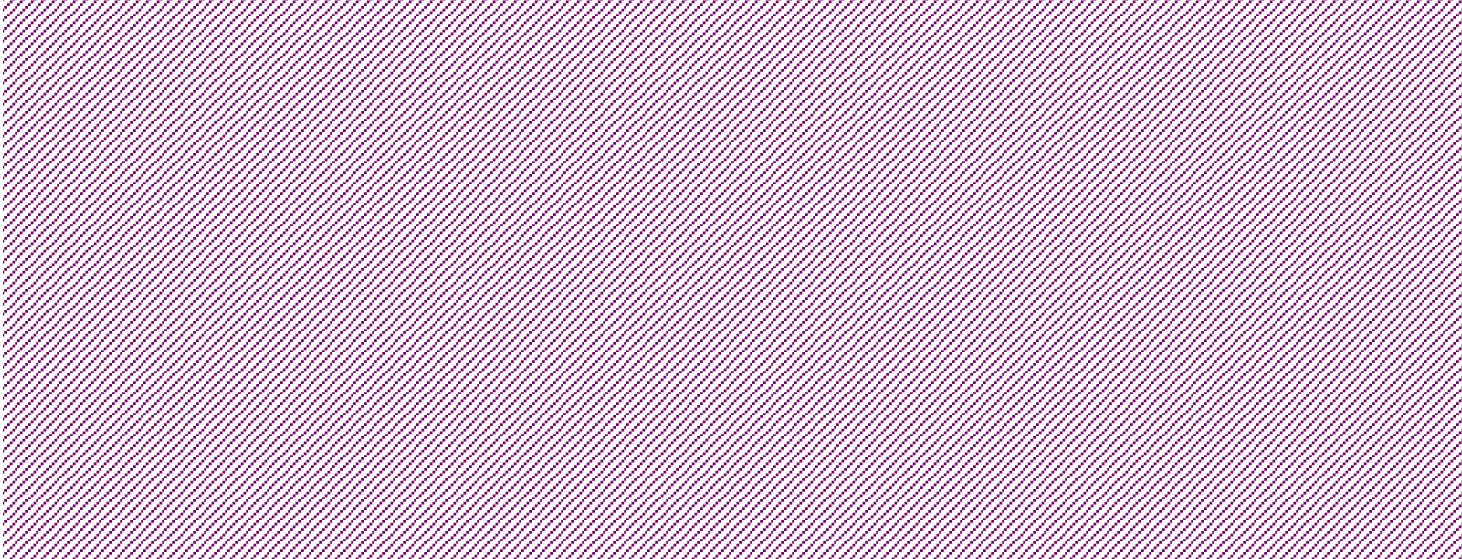

Figure 10. Biomass supply per month (2017).

\subsection{Earth to Air Heat Exchanger (EAHX)}

Figure 11 shows the evolution of the energy saved by the EAHX system for 2017. The periods when the EAHX achieves the highest energy savings are May-June. The main reason for this fact is not the transient thermal behavior of the ground, but the operating times of the system. Due to the AHU control algorithm described in Section 2.1 and the typical climate of Valladolid, the economizer operates during most of wintertime (given the great temperature differences between indoors and outdoors) whereas free cooling is usually the most efficient option during springtime. Hence, the EAHX operation concentrates during early summer period and remains noticeably important along the following months.

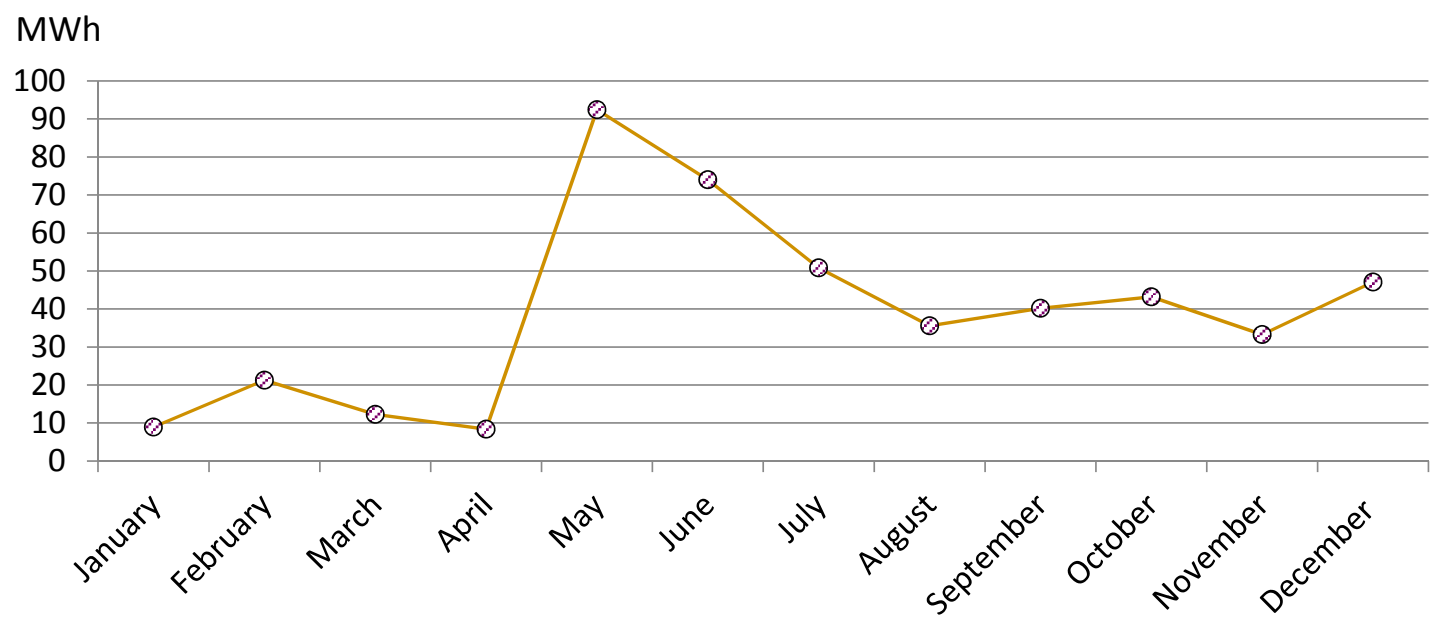

Figure 11. Energy supplied by EAHX per month for 2017, in MWh.

\subsection{Photovoltaic Modules}

Electric energy consumed by the LUCIA nZEB is generated by autonomous systems. The monitoring analysis shows that the PV modules supply $12 \%$ of the building's electricity generation. This building is designed to operate primarily with on-site generated electricity.

From the PV electricity generation data, shown in Figure 12, PV 1 entail the highest electricity production load, compared to the other 3. This is mainly due to the high-efficiency type of the PV modules, despite the larger total surface covered by the three PV modules on the roof, besides the more favorable orientation. From these results, an average electricity generation of $980 \mathrm{kWh}$ can be expected all throughout the year. 


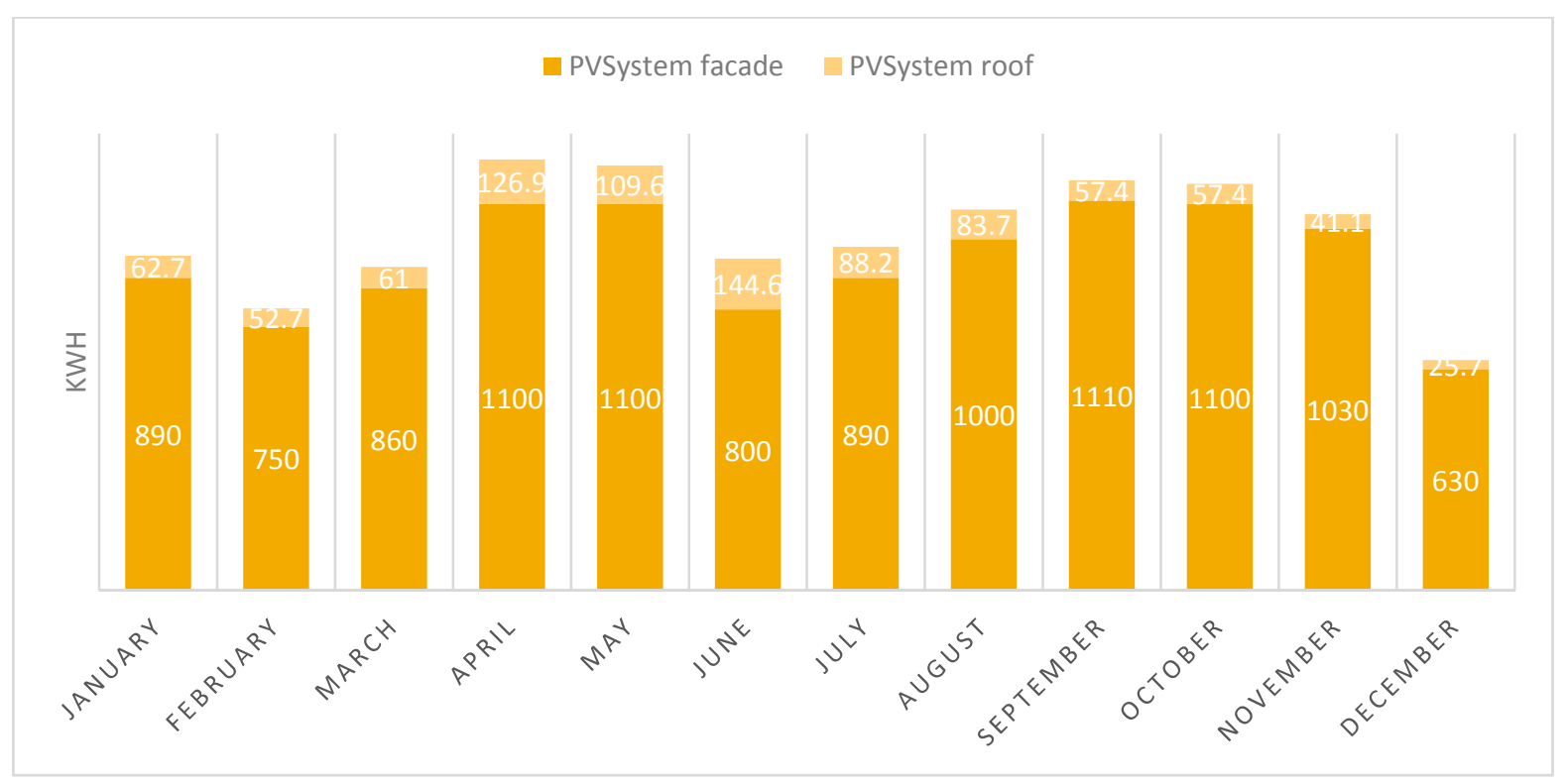

Figure 12. Electricity Generation by PV modules during the Year 2017.

PV generation is higher during mid-season months than during summer months, despite daytime being longer during the latter. This can be due to the less favorable orientation and slope of the most efficient PV system, that of the façade. Indeed, it can be observed that for June, when solar height is the highest, the energy generated by the PV installed within the roof skylights increases whereas the energy generated by the façade PV diminishes.

\subsection{Environmental Impact: $\mathrm{CO}_{2}$ Emissions Savings}

In accordance with the previously mentioned European directives, reference is made to the importance of the reduction of $\mathrm{CO}_{2}$ emissions in the generation of energy associated with buildings. Consequently, another objective of this paper is to characterize the savings in $\mathrm{CO}_{2}$ emissions achieved thanks to the operation of these renewable energy technologies installed in the LUCIA.

Table 4 gathers the $\mathrm{CO}_{2}$ emissions saved in kg during 2017 through the use of the systems that are currently in service at the building. The emissions saved related to PV electricity generation are obtained in comparison to the mix of electrical energy generated in Spain, through the conversion factors defined in by the Spanish standards. Conversion factors for biomass and conventional fuels determined for Spain are used to quantify the $\mathrm{CO}_{2}$ emissions saved related to the EAHX and the biomass boiler. The following conversion factors have been used for the valuation of $\mathrm{CO}_{2}$ emissions: Electricity $0.357 \mathrm{~kg} \mathrm{CO} / \mathrm{kWh}$; Diesel $0.311 \mathrm{~kg} \mathrm{CO}_{2} / \mathrm{kWh}$; LPG $0.254 \mathrm{~kg} \mathrm{CO}_{2} / \mathrm{kWh}$ and natural gas $0.252 \mathrm{~kg} \mathrm{CO} / \mathrm{kWh}$. All in accordance with the factors defined by Spanish standards [33].

Table 4. $\mathrm{CO}_{2}$ emission savings $(\mathrm{kg})$ vs. conventional fuels by renewable energy systems at the nZEB LUCIA in 2017.

\begin{tabular}{|c|c|c|c|c|}
\hline \multirow{3}{*}{ Electrical (kg CO $2 /$ Year) } & \multirow{3}{*}{ PVSystems } & $\mathbf{P V}_{\text {facade }}+$ roof & $\mathbf{P V}_{\text {facade }}+$ roof & $\mathbf{P V}_{\text {facade }}+$ roof \\
\hline & & 7899 & 7899 & 7899 \\
\hline & & Natural Gas & Diesel & LPG \\
\hline \multirow{2}{*}{ Thermal (kg CO 2 /year) } & EAHX System & 95,350 & 134,144 & 114,046 \\
\hline & biomass boiler & 20,202 & 28,421 & 24,163 \\
\hline TOTAL (kg CO 2 /year) & & 123,451 & 170,464 & 146,107 \\
\hline
\end{tabular}


First of all, PV savings are near 8 tons of $\mathrm{CO}_{2} /$ year. Savings in carbon emissions through the use of the EAHX are in the range of 95 tons $\mathrm{CO}_{2}$ /year, for natural gas, to 134 tons $\mathrm{CO}_{2}$ /year for diesel, all according to the European regulation of emissions.

Concerning the emissions saved by the biomass boiler, the burning of biomass in comparison with other fuels, has the benefit of being considered not only renewable but also low carbon emissions, covers a range from 20 tons $\mathrm{CO}_{2}$ /year if the fuel consumed was natural gas, to 28 tons $\mathrm{CO}_{2}$ /year if the fuel consumed were diesel.

Concerning the total emissions saved by the ensemble of the three renewable energy systems with respect to the traditional non-renewable fuels, plus the contribution of electric energy supplied from the grid, the diesel is the most unfavorable fuel, exceeding 170 tons $\mathrm{CO}_{2}$ /year, followed by liquefied petroleum gas (LPG) and natural gas.

\subsection{Operating Costs Saving}

Other important sections of this paper focus on the economic savings generated on the LUCIA nZEB by all the renewable energy systems that are currently operating in the LUCIA building due to the use of various renewable resources, without analysing the investment costs of the systems.

The economic analysis has been carried out following the Spanish fuel price policy in 2017, in the official currency unit of the European Central Bank. Table 5 shows the economic savings generated by the various systems. Firstly, the photovoltaic generation offers savings of $1460 €$ from the photovoltaic systems implemented. It can be seen that the roof photovoltaic systems installed together barely exceed $7 \%$ of the total photovoltaic economic savings.

The following two systems implemented in the LUCIA building provide a comparison of their economic savings versus fuels frequently used in traditional building construction. The EAHX generates economic savings of around 19,000 € more than if biomass were used to obtain the $\mathrm{kWh}$ saved by the EAHX.

Focusing on traditional fuels, the comparison is in the range from $23,889 €$ for Natural Gas to $27,937 €$ that would be saved in generation respectively by the use of a fossil fuel such as Diesel.

The biomass boiler has economic savings for biomass use from $18,222 €$ per year with the use of Natural Gas, to $21,309 €$ that would be saved by the use of Diesel, as shown in Table 5.

Table 5. Saving $€ /$ year vs. different fuels.

\begin{tabular}{cccccc}
\hline \multirow{2}{*}{ Electrical ( $($ /year) } & \multirow{2}{*}{ PVSystems } & \multirow{2}{*}{ Biomass } & $\mathbf{P V}_{\text {facade }+ \text { roof }}$ & $\mathbf{P V}_{\text {facade }+ \text { roof }}$ & $\mathbf{P V}_{\text {facade }}+$ roof \\
\cline { 4 - 6 } & & & $\mathbf{1 4 6 1}$ & $\mathbf{1 4 6 1}$ & $\mathbf{1 4 6 1}$ \\
\cline { 4 - 6 } & & Natural Gas & Diesel & LPG \\
\hline \multirow{2}{*}{ Thermal ( $(/$ year) } & EAHX System & \multirow{2}{*}{18,696} & 28,889 & 27,937 & 26,642 \\
& Biomass boiler & & 18,222 & 21,309 & 20,321 \\
\hline \multirow{2}{*}{ Total ( $€ /$ year) } & & 18,696 & 43,573 & 50,707 & 48,423 \\
\hline
\end{tabular}

The total savings in operating costs achieved by the sum of the three systems in comparison to the traditional fuels, plus the extra cost of the electricity supply supplied from the grid, show that diesel is the most unfavorable fuel, exceeding 50,000 €/year, followed by LPG and natural gas. Moreover, without the EAHX, the building would require an additional sum of $1560 € /$ month due to extra biomass consumption.

\section{Conclusions}

This study has focused on the renewable energy technologies implemented in the LUCIA building, a reference nZEB belonging to the University of Valladolid, equipped with photovoltaic systems, an Earth Air Heat Exchanger and a biomass boiler. The target building was designed to serve as a 
real life laboratory for the study of the applicability of these innovative energy efficiency strategies in further nZEB to be built in a similar climate.

The dynamic monitoring of different energy parameters is going on and the systems operation is controlled through a SCADA, which provides detailed information on the breakdown of energy consumed in the building. However, further breakdown of the monitoring could give evidence of the energy consumed by the fans and pumps of each particular system.

An energy analysis of the building has been carried out in order to know in detail the actual behavior of the strategies implemented, the energy consumption and the consequent savings on energy and $\mathrm{CO}_{2}$ emissions. The results show that implementation of these strategies instead of conventional solutions could reduce the emissions up to 120 to 170 tons, thus minimizing the environmental impact. The paper has also come across the economic costs entailed by the operation of these renewable energy systems, estimating the economic savings between 20,000 and 50,000 €/year compared to the use of conventional fuels, thus concluding that the useful life of these technologies would be of low cost.

Results show that this multipurpose building of the tertiary sector present little demand of DHW, whereas indoor heating accounts for about $36 \%$ of the energy demand. Half of the total energy consumption is due to cooling requirements. The evolution throughout the year of the energy demanded for cooling, heating and lighting corresponds to the expected relation with the outdoor conditions.

Electricity generated by the three PV systems installed in the roof is negligible compared to the energy generated by the façade PV modules, despite the larger total surface covered by the roof PV modules. In addition to the fact that their position (orientation, slope) is less favorable, this highlights that installing high-efficiency PV modules is a key factor, as already extracted from the existing literature.

Concerning the EAHX, savings achieved sharply increase from springtime to the early summer period, then diminishing to and maintaining at about $40 \mathrm{MWh}$ during summer and autumn. These results are due to the control algorithm implemented in the SCADA. Because free-cooling turns to be the most interesting strategy for reducing ventilation thermal demand during spring, being heat recovery the best option during winter, operation of the EAHX is limited, despite the non-negligible temperature drops achievable by the system throughout the whole year.

The biomass results to be an interesting strategy to meet the heating loads, given its availability in the region where the building is located and the short-term return on investment that can be expected thanks to the low operating costs related in comparison with other fuels.

Values measured serve as a reference to export management and design strategies to other nZEB with similar characteristics in the same region. In this sense, reconsideration of some features during the design stage would be recommendable: implementation of EAHX may have little effect on the combined ventilation system despite the high efficiency achievable if operating alone and free-cooling potential should be maximized through a revised control algorithm, extending its operation to the whole nighttime during summer. Future work on the Life Cycle Analysis and return of investment could complete the required guidelines for the optimal design of nZEB in similar climates.

Author Contributions: Conceptualization, F.J.R.-M.; Data curation, J.M.R.-H. and S.L.G.-G.; Formal analysis, J.M.R.-H., J.F.S.J.-A., E.V.-G., F.J.R.-M. and A.T.-G.; Investigation, J.M.R.-H. and J.F.S.J.-A.; Methodology, J.F.S.J.-A., E.V.-G. and F.J.R.-M.; Software, J.M.R.-H. and S.L.G.-G.; Supervision, J.F.S.J.-A., E.V.-G. and F.J.R.-M.; Writing—original draft, J.M.R.-H.; Writing—review \& editing, A.T.-G.

Funding: This research received no external funding.

Acknowledgments: This work is part of the research that is being carried out within the framework of the "Desarrollo de un gestor inteligente de redes térmicas GIRTER." financed by the Spanish government through the research program RETO (Ref.: RTC-2016-5800-3). Its publication is funded by ITAP, which is an university research institute of multiple areas of knowledge from Engineering School and Medical School at the University of Valladolid.

Conflicts of Interest: The authors declare no conflict of interest. 


\section{Abbreviations}

$\begin{array}{ll}\text { LUCIA } & \text { Lanzadera Universitaria de Centros de Investigación Aplicada } \\ \text { nZEB } & \text { near Zero Energy Building } \\ \text { EAHX } & \text { Earth Air Heat eXchanger } \\ \text { PV } & \text { PhotoVoltaics } \\ \text { EU } & \text { European Union } \\ \text { EREC } & \text { European Renewable Energy Council } \\ \text { EPBD } & \text { European Performance Building Directive } \\ \text { HVAC } & \text { Heat Ventilation Air Conditioning } \\ \text { DHW } & \text { Domestic Hot Water } \\ \text { RER } & \text { Renewable Energy Ratio } \\ \text { CHP } & \text { Central Heat Power } \\ \text { EER } & \text { Energy Efficiency Ratio } \\ \text { DALI } & \text { Digital Addressable Lighting Interface } \\ \text { LED } & \text { Light-Emitting Diode } \\ \text { SCADA } & \text { Supervisory Control and Data Acquisition } \\ \text { LEED } & \text { Leadership in Energy \& Environmental Design } \\ \text { LHV } & \text { Low Heating Value } \\ \text { AHU } & \text { Air Handling Unit } \\ \text { IAQ } & \text { Indoor Air Quality }\end{array}$

\section{References}

1. 2030 Climate \& Energy Framework; European Council of 23 and 24 October 2014; European Council: Brussels, Belgium, 2014.

2. European Renewable Energy Council (EREC). Available online: https:/ / ec.europa.eu/energy/intelligent/ projects/en/partners / european-renewable-energy-council-1 (accessed on 10 September 2018).

3. The European Parliament and the Council of the European Union. DIRECTIVE (EU) 2018/844 of the European Parliament and of the council of 30 May 2018 amending Directive 2010/31/EU on the energy performance of buildings and Directive 2012/27/EU on energy efficiency. Off. J. Eur. Union 2018, 156, 75-91.

4. Oh, J.; Hong, T.; Kim, H.; An, J.; Jeong, K.; Koo, C. Advanced strategies for net-zero energy building: Focused on the early phase and usage phase of a building's life cycle. Sustainability 2017, 9. [CrossRef]

5. Deng, S.; Wang, R.Z.; Dai, Y.J. How to evaluate performance of net zero energy building-A literature research. Energy 2014, 71, 1-16. [CrossRef]

6. Rey-Hernández, J.M.; Velasco-Gómez, E.; San José-Alonso, J.F.; Tejero-González, A.; Rey-Martínez, F.J. Energy analysis at a near zero energy building. A case-study in Spain. Energies 2018, 11. [CrossRef]

7. Tsalikis, G.; Martinopoulos, G. Solar energy systems potential for nearly net zero energy residential buildings. Sol. Energy 2015, 115, 743-756. [CrossRef]

8. González-González, S.L.; Tejero-González, A.; Rey-Martínez, F.J.; Andrés-Chicote, M. Alternative for summer use of solar air heaters in existing buildings. Energies 2017, 10, 1-16. [CrossRef]

9. Good, C.; Andresen, I.; Hestnes, A.G. Solar energy for net zero energy buildings-A comparison between solar thermal, PV and photovoltaic-thermal (PV/T) systems. Sol. Energy 2015, 122, 986-996. [CrossRef]

10. Peretti, C.; Zarrella, A.; De Carli, M.; Zecchin, R. The design and environmental evaluation of earth-to-air heat exchangers (EAHE). A literature review. Renew. Sustain. Energy Rev. 2013, 28, 107-116. [CrossRef]

11. Ascione, F.; D'Agostino, D.; Marino, C.; Minichiello, F. Earth-to-air heat exchanger for NZEB in Mediterranean climate. Renew. Energy 2016, 99, 553-563. [CrossRef]

12. Thiers, S.; Peuportier, B. Thermal and environmental assessment of a passive building equipped with an earth-to-air heat exchanger in France. Sol. Energy 2008, 82, 820-831. [CrossRef]

13. Bruno, R.; Arcuri, N.; Carpino, C. The Passive House in Mediterranean Area: Parametric Analysis and Dynamic Simulation of the Thermal Behaviour of an Innovative Prototype. Energy Procedia 2015, 82, 533-539. [CrossRef]

14. Vaz, J.; Sattler, M.A.; Brum, R.D.S.; Dos Santos, E.D.; Isoldi, L.A. An experimental study on the use of Earth-Air Heat Exchangers (EAHE). Energy Build. 2014, 72, 122-131. [CrossRef] 
15. Woodson, T.; Coulibaly, Y.; Traoré, E.S. Earth-Air Heat Exchangers for Passive Air Conditioning: Case study Burkina Faso. J. Constr. Dev. Ctries. 2012, 17, 21-33.

16. Bisoniya, T.S.; Kumar, A.; Baredar, P. Experimental and analytical studies of earth-air heat exchanger (EAHE) systems in India: A review. Renew. Sustain. Energy Rev. 2013, 19, 238-246. [CrossRef]

17. Niu, F.; Yu, Y.; Yu, D.; Li, H. Investigation on soil thermal saturation and recovery of an earth to air heat exchanger under different operation strategies. Appl. Therm. Eng. 2015, 77, 90-100. [CrossRef]

18. Mohamed, A.; Hasan, A.; Sirén, K. Fulfillment of net-zero energy building (NZEB) with four metrics in a single family house with different heating alternatives. Appl. Energy 2014, 114, 385-399. [CrossRef]

19. Moran, P.; Goggins, J.; Hajdukiewicz, M. Super-insulate or use renewable technology? Life cycle cost, energy and global warming potential analysis of nearly zero energy buildings (NZEB) in a temperate oceanic climate. Energy Build. 2018, 139, 590-607. [CrossRef]

20. Yang, A.S.; Su, Y.M.; Wen, C.Y.; Juan, Y.H.; Wang, W.S.; Cheng, C.H. Estimation of wind power generation in dense urban area. Appl. Energy 2016, 171, 213-230. [CrossRef]

21. Drysdale, D.; Mathiesen, B.V.; Paardekooper, S. Transitioning to a $100 \%$ renewable energy system in Denmark by 2050: Assessing the impact from expanding the building stock at the same time. Energy Effic. 2018, 1-19. [CrossRef]

22. Kampelis, N.; Gobakis, K.; Vagias, V.; Kolokotsa, D.; Standardi, L.; Isidori, D.; Cristalli, C.; Montagnino, F.M.; Paredes, F.; Muratore, P.; et al. Evaluation of the performance gap in industrial, residential \& tertiary near-Zero energy buildings. Energy Build. 2017, 148, 58-73. [CrossRef]

23. Torgal, F.P.; Mistretta, M.; Kaklauskas, A.; Granqvist, C.G.; Cabeza, L.F. Nearly Zero Energy Building Refurbishment: A Multidisciplinary Approach; Springer: London, UK, 2014; ISBN 9781447155232.

24. Carlisle, N.; Van Geet, O.; Pless, S. Definition of a "Zero Net Energy" Community; US National Renewable Energy Laboratory: Lakewood, CO, USA, 2009.

25. Kottek, M.; Grieser, J.; Beck, C.; Rudolf, B.; Rubel, F. World map of the Köppen-Geiger climate classification updated. Meteorol. Z. 2006, 15, 259-263. [CrossRef]

26. Tejero-González, A.; Andrés-Chicote, M.; García-Ibáñez, P.; Velasco-Gómez, E.; Rey-Martínez, F.J. Assessing the applicability of passive cooling and heating techniques through climate factors: An overview. Renew. Sustain. Energy Rev. 2016, 65, 727-742. [CrossRef]

27. LEED Certification. Available online: https://new.usgbc.org/leed (accessed on 10 September 2018).

28. Rey-Hernandez, J.M.; Yousif, C.; Gatt, D.; Velasco-Gomez, E.; San José-Alonso, J.; Rey-Martínez, F.J. Modelling the long-term effect of climate change on a zero energy and carbon dioxide building through energy efficiency and renewables. Energy Build. 2018, 174, 85-96. [CrossRef]

29. Austrian Standards (Önorm). Available online: https://www.austrian-standards.at/ (accessed on 10 September 2018).

30. Wilde, P. De Automation in Construction The gap between predicted and measured energy performance of buildings: A framework for investigation. Autom. Constr. 2014, 41, 40-49. [CrossRef]

31. SIEMENS DESiGo. Available online: http://www.buildingtechnologies.siemens.com/bt/global/en/ buildingautomation-hvac/building-automation/building-automation-and-control-system-europedesigo/management-station/desigo-web/pages/desigo-web.aspx (accessed on 10 September 2018).

32. ModBUS Protocol. Available online: http://www.modbus.org/ (accessed on 10 September 2018).

33. Spanish Institute for Energy Saving and Diversification (IDAE) $\mathrm{CO}_{2}$ Conversion Factors. Available online: http://www.mincotur.gob.es/energia/desarrollo/EficienciaEnergetica/RITE/Reconocidos/ Reconocidos/Otrosdocumentos/Factores_emision_CO2.pdf (accessed on 4 September 2018).

(C) 2018 by the authors. Licensee MDPI, Basel, Switzerland. This article is an open access article distributed under the terms and conditions of the Creative Commons Attribution (CC BY) license (http://creativecommons.org/licenses/by/4.0/). 